\title{
Disruptive or disrupted? A qualitative study on the construction of indiscipline
}

\author{
Marta Araújo* \\ Institute of Education, University of London, UK
}

This paper examines current official discourses on school discipline in Britain. It analyses New Labour's recent documents in education, such as the party's manifestos, Green and White papers, and official guidelines, to understand which particular understandings of discipline are being promoted. In spite of a political commitment to social inclusion, New Labour's current discourses on discipline do not affect all pupils equally. A conception of indiscipline as originating at the home and predominantly in certain cultural and social backgrounds has been proposed, which may be deepening social inequalities in education. The paper concludes that one needs to depart from a bipolar conception of indiscipline (that promotes a view of pupils as being either disruptive or disrupted), which disadvantages the pupils from certain minority ethnic backgrounds. The paper also suggests that context and school institutional and organizational processes must be taken into account if one is to promote social justice in disciplinary matters.

Schools need to know that the Government is on their side and the community is on their side against unruly children and abusive parents.

(Blair, 2002)

\section{Introduction}

When New Labour won the 1997 General Election, there were high expectations that key changes in education policy would take place, particularly in relation to issues of social justice. With the principle 'to benefit the many, not the few', Education Secretary David Blunkett emphasized that he was committed to raise the quality of education provided in all schools, for all pupils (DfEE, 1997, p. 11). This could be seen as a commitment to social justice that was absent from discourses of previous Conservative Governments. And indeed, spending in the area of social inclusion increased under New Labour (Hill, 2001; Power \& Gerwitz, 2001). Also,

\footnotetext{
${ }^{\star}$ Centre for Social Studies, University of Coimbra, Colégio de S. Jerónimo, Apartado 3087, 3001-
} 401 Coimbra, Portugal. Email: marta@ces.uc.pt 
a Social Exclusion Unit (SEU) was set in 1997 by the government, which established social inclusion as a policy priority of New Labour (Alexiadou, 2002). With the involvement of the SEU in the making of current guidance on discipline for schools, New Labour promoted the view that this too was a matter of social inclusion. Nonetheless, many authors have suggested that there is a contradiction between New Labour's move towards social inclusion and current policies in education that promote competition, selection and exclusion (e.g. Barton \& Slee, 1999; Demaine, 1999; Edwards et al., 1999; Hill, 2001). This is because New Labour has largely built on the principles of choice and diversity (DfE, 1992) promoted by the Conservative Party (the Tories). In fact, there are important similarities in the education policies put forward by recent Conservative and Labour Governments, such as the focus on 'standards' and the support for a quasi-market in education (Demaine, 1999; Hill, 2001). This approach to education policy has been shown to disadvantage pupils from particular social and ethnic backgrounds (Gillborn \& Youdell, 2000), and thus it can be argued that New Labour's discourses on social inclusion were not accompanied by serious action to tackle structural inequalities in the education system. Indeed, as New Labour is committed to tackle 'standards not structures' (DfEE, 1997, p. 5), it is the symptoms rather than the causes that are being attacked (Webster, 2001).

This paper aims then to expand previous work and to explore the tensions and contradictions in conceptions of discipline. I will show that these are further differentiating the educational experiences of pupils of particular social and ethnic backgrounds, thus questioning New Labour's commitment to engage with the deep-seated nature of educational inequalities.

In spite of official reports declaring that indiscipline is a serious problem in only a minority of schools (OFSTED, 2001), this is an issue of growing concern in the UK. Dean (1998), for instance, suggested that parents are more concerned with how their child's school deals with discipline than with academic 'standards'. Issues of discipline and control were also prioritized at the school where I conducted the study on which this paper draws.

\section{The school}

Greenfield Comprehensive ${ }^{1}$ was not just like any other school. It had been given a Fresh Start, ${ }^{2}$ which consisted in the closure of the school considered 'failing', and in its re-opening with a new name and staff, and improved facilities. The initiative was meant to be an official response to what were judged to be unacceptably low levels of attainment. Changing the school management and teaching staff, creating a new identity for the school and offering new facilities and equipment were some of the measures implemented to bring about higher academic achievement. In a school in such circumstances, matters directly related to attainment (such as resources, curricula innovation or pedagogy), were meant to be of the foremost importance. However, at Greenfield Comprehensive, the need to 'keep the lid on', as one teacher put it, to prevent minor situations of conflict escalating into a full-scale riot permeated the 
school's daily life. This was particularly true after the first headteacher resigned. Aiming to give pupils more responsibility, he believed in diminished disciplinary sanctions for non-violent behaviour. However, after a violent incident taking place in the school premises his vision was questioned. As he eventually resigned, the headteacher who took office implemented a more pragmatic approach, introducing a more structured and organized management in the school. The fresh identity of the school was broadly based on conceptions of discipline and control: with $\mathrm{Mr}$ Jones, rules were more and tighter, and so 'the students are getting away with less' (Ms Babbra, Science teacher).

Greenfield Comprehensive is an inner-city, multi-ethnic school, with a roll of over 600 pupils. Over half of these were eligible to receive free school meals and well over one-third received support for English as an Additional Language. Of pupils on roll, $15 \%$ became refugees ${ }^{3}$ in the UK, originating mainly from Somalia, Turkey, Kurdistan and Albania. When I started fieldwork, in November 1999, the school had just been re-launched with a different name, a new head teacher and staff, and improved facilities by virtue of its Fresh Start status.

\section{Methodology}

This paper draws on a study that looked at pupils' and teachers' daily experiences at an inner-city, multi-ethnic, comprehensive school, paying particular attention to issues of discipline, selection and the construction of pupil identities. Using ethnography as a research strategy, I conducted fieldwork for approximately 18 months. The study focused particularly on a form in Year 7 ( 11 year olds). Year 7 was chosen as pupils are newcomers to a school, which could help in understanding the ways in which reputations and identities are constructed. The form I observed was selected by the headteacher to comply with my requirements: a balanced gender, ethnic and social composition.

In my study, the methods used were observation, interviews, and the collection of school documents. Observation focused particularly on lessons, but also included two school assemblies and a day of meetings with parents. I observed 18 Science and nine PSE lessons. The choice of these subjects had to do with the different status they have in school and therefore the different atmospheres that are promoted in each classroom. All of these were tape-recorded, and notes were taken and written down in an unstructured fashion. They were transcribed soon after the observation took place. Interviews were semi-structured, with open-ended questions. There were two rounds of interviews with pupils. The first set of interviews was conducted in friendship groups of two, with a total of 23 pupils out of the 26 that were in the form under study. ${ }^{4}$ The interviews were used to elicit pupils' accounts of their experiences in school, preference of subjects and teachers, issues of discipline and behaviour, interactions with teachers and other pupils and images of an 'ideal' pupil (Becker, 1952). Follow-up interviews were carried out individually when pupils were in their Year 8 (aged 12). ${ }^{5}$ Generally, interviews with teachers aimed to account for their previous and present teaching experiences, understand how they 
perceived the school's atmosphere, to elicit their images of pupils in $7 \mathrm{~B}$ in relation to issues of academic achievement and discipline, and how they positioned these in relation to their conceptions of an 'ideal' pupil (Becker, 1952). Interviews with school staff were initially carried out with the PSE teacher (also Head of the Student Services), the Science teacher (also Head of Year 7) and the form tutor. Additionally, I tried to interview as many teachers as possible, amongst those who had had contact with the pupils in the form under study. These were their Year $7 \mathrm{PE}$ and Music teachers, and two Science teachers in Year 8. I also repeated the interviews with 7B's Science teacher and the form tutor, trying to understand what changes had occurred in the school in the meantime. Interviews were carried out with two learning mentors to know their views on the pupils in $7 \mathrm{~B}$ they worked with and to identify the kind of support they provided. Finally, I interviewed the headteacher twice, trying to elicit his experiences as Head of Greenfield Comprehensive, and to obtain his account of the aims and implementation of the Fresh Start initiative. Interviews were recorded and transcribed. Finally, school documents were also collected. The main documents to which I had access were: the school prospectus, timetables and day plans, documents on the school's policy on discipline, on Special Educational Needs (SEN), a table of 7B's achievement in Science, and pupils' personal records.

The data were analysed using a loose version of Grounded Theory as proposed by Glaser \& Strauss (1967), and particularly the method of 'open coding' (Strauss \& Corbin, 1998). After the data were transcribed and I became familiar with it, I looked for common themes. I then developed categories for coding segments of text, and developed a codebook, where the meaning, boundaries and examples of each category were written down. After reaching stable categories, I attempted in the subsequent analysis to establish relationships between those and sub-categories in order to achieve a more complete understanding of the phenomena under study.

\section{New Labour's official discourses on indiscipline}

Broadly, the current guidance for discipline in primary, middle and secondary schools was set in Circular 10/99 - Social inclusion: Pupil support (DfEE, 1999e). ${ }^{6}$ The document was issued jointly by the Department for Education and Employment (DfEE) with the Social Exclusion Unit (SEU), the Department of Health and the Home Office, and was contextualized in a wider policy of social inclusion, aiming at the reduction of unemployment and crime rates. Under the Education Standards and Framework Act 1998 (HMSO, 1998), head teachers, governing bodies and LEAs shall observe guidance issued by the Secretary of State. Besides this circular and the Education Acts 1998 and 2002 (HMSO, 2002), other education documents refer to this issue, such as Green and White Papers on Education, and political manifestos. They were thus considered with a view to disentangle which conceptions of indiscipline are being proposed by official discourses, which has 
important implications for the role of education and schools in promoting social inclusion.

\section{Why indiscipline happens}

The official documents analysed put forward a number of reasons for, or causes of, indiscipline. Amongst them are the pupil's home, the school, and the community where the school is located. Strikingly, the most cited cause is poor parenting. In every document analysed, parents are associated with a child's misbehaviour. And in some documents, indiscipline is only addressed when the role of parents in education is being dealt with. This is the case in the Labour Party's manifestos to the 1997 and 2001 general elections, and in the Green Paper Schools Building on Success (DfEE, 2001a). The following quote is illustrative of the home being presented as a priori responsible for a child's indiscipline:

Misbehaviour doesn't begin in school, but can often be carried into school. That is why we will ensure that the law is enforced in those exceptional cases where every other method has been tried, yet parents continue to show a wilful disregard for their children's educational welfare.

(Labour Party, 1995, p. 31, emphasis added)

Here, indiscipline is presented as a problem that emerges in the home and that is carried into school. Importantly, it is based on a deficit view of parents, who are to be punished rather than supported. The 'breakdown in the certainties of family life' (DfEE, 2001a, p. 13), along with poor parenting skills and parents' low expectations are presented as the reasons for the current situation of indiscipline in schools:

we also know that much misbehaviour arises from indiscipline and lack of interest in the home. We will therefore seek to strengthen the hand of heads and teachers in dealing with parents whose children's behaviour or attendance at school is unacceptable.

(DfEE, 2001a, p. 60, emphasis added)

Such a bleak vision of parenting is prevalent across documents on education and discipline. This discourse of a parenting deficit has been noted by other authors. ${ }^{7}$ In a piece of research on home-school relationships under New Labour's Government, carried out by Vincent \& Tomlinson (1997), it was suggested that even in initiatives to promote parental involvement in education, those coming from disadvantaged communities tend to be positioned as 'problematic'. Gamarnikow \& Green (1999), in their reading of Education Action Zones bids also suggested that in New Labour's discourses, 'problematic' families tend to be equated with single parents, those from working-class backgrounds, and (as I will explore) families from ethnic minorities. Thus, discourses on poor parenting help to promote the view that disruptive pupils come from particular social and ethnic backgrounds. Promoting this view may disadvantage these pupils' educational opportunities, thus questioning New Labour's commitment to social justice. 
Whilst responsibility for indiscipline is generally shifted onto parents, teachers are mainly presented as its victims:

The Chief Inspector of Schools' 1999-2000 annual report indicates that last year there was the first small rise in behaviour problems for some time and that in some schools even good teachers are severely tested by some of the behaviour pupils bring with them into the school.

(DfEE, 2001a, p. 59, emphasis added)

Teachers are presented as being tested or challenged by pupils' indiscipline, which is seen as being acquired at home. The strong emphasis of the problem of indiscipline as resulting from poor parenting and as a problem of individual pupils sits uncomfortably with a prescription of an active role for schools to play. The conception of indiscipline being put forward presupposes that it exists before, and independently of, pupils' experiences of schooling. As a result, there is little room for schools and teachers to prevent indiscipline, and the role given to school is rather related to the amelioration/remediation of the indiscipline that is seen as acquired at home. The White Paper Excellence in Schools (DfEE, 1997), for instance, states that 'schools can also act directly to improve pupil behaviour' (p. 55), through the development and implementation of their own policy on behaviour. This should set boundaries of behaviour and define a system of sanctions and rewards, which is to be made clear to all (staff, pupils and parents), and applied consistently (Labour Party, 1995; DfEE, 1997, 1999a). The school's development of a strong ethos and sense of purpose is also seen as improving indiscipline (DfES, 2001). Schools and teachers are given a more active role in promoting indiscipline in Circular 10/99 - Social inclusion: Pupil support (DfEE, 1999a). In the letter that accompanies the circular, several school factors that influence school discipline are identified:

Good teaching, sound behaviour management, effective anti-bullying policies, clear rewards, consistently applied sanctions and imaginative use of the curriculum all make a difference, and reinforce the message that all young people can achieve their full potential.

(DfEE, 1999a)

These measures are seen as making a difference in terms of pupil behaviour between schools facing 'similar challenges' (DfEE, 1999a, p. 1). However, the school measures proposed in this letter to deal with indiscipline do not translate into actual guidance for schools. The advice given throughout the circular focuses mostly on support for pupils, and ends up shifting the problem of indiscipline onto them. For instance, it is pointed out that misbehaviour might be related to 'a pupil's problems in understanding lessons' (DfEE, 1999a, para. 2.1), or 'unidentified or unmet special educational needs' (para. 3.1), for which they should be provided with additional support. This does not only concentrate the problem on pupils, as it dismisses the role of teachers, by not allowing the possibility that a pupil's misbehaviour and lack of interest in a lesson can result from poor teaching. Interestingly, whenever the role of teaching is mentioned it is in terms of how staff will be supported in dealing with poor behaviour (e.g. DfES, 2001). Thus, it is not considered that the school and teachers have a role in producing indiscipline, for instance through conflictive 
social interactions between teachers and pupils, or failure to resolve disputes between pupils.

The shifting of the problem of indiscipline onto pupils (and their families) has been noted by Slee (1995), who suggests that this is an approach that has stemmed from 'the growing influence of educational psychology' (p. 62). Slee also argues that this approach is particularly appealing for policy-makers, schools and teachers, as it implicitly promotes simplistic 'quick-fix' solutions, centring intervention on the pupil rather than on the school organization, pedagogy or the curriculum.

Besides the role given to the pupils, their parents and schools in indiscipline, the community where the school is located is also the focus of some of New Labour's documents on education. But it is the inner-city communities that are presented as being 'problematic' in terms of discipline. The initiative Excellence in Cities (DfEE, 1999b), which includes several measures to tackle indiscipline specifically in innercity schools (such as the provision of learning mentors), is testimony to this. Importantly, the launch document helps the association between issues of indiscipline and the pupils from socially disadvantaged and/or ethnic minority communities, through the use of 'race' signifiers such as 'inner city' and 'problem' (Stanford, 2001; also Power \& Gerwitz, 2001). This association is also noticeable in the White Paper Schools Achieving Success (DfES, 2001), where the initiative Excellence in Cities is analysed. In the document it is argued that 'Secondary education faces its biggest challenge in our inner city areas where schools and the communities they serve are often under the greatest pressure' (DfES, 2001, p. 15). The reasons given for this are:

\footnotetext{
Many teachers working in inner city schools, for example, teach large numbers of children for whom English is not their first language and who may have moved school, or country, several times. In some schools, teachers face endemic poor discipline and pupil disaffection. In part, this is because some pupils arrive at school with too little understanding of how they must behave.
}

(DfES, 2001, p. 15)

In sum, a deficit approach to the communities and families of certain social and ethnic backgrounds features prominently in official discourses. Thus, it is the same people that are supposed to be supported who end up being blamed. Such deficit approach of disadvantaged communities and families, added to its association with the problem of indiscipline, is potentially disadvantaging for pupils coming from these backgrounds, as these tend to be perceived as more likely to misbehave. Furthermore, and as Parsons (1999) suggested, this shifting of the problem onto the children and their families dismisses any causes at policy and institutional levels.

\section{Why indiscipline matters}

I explored in the previous section how official discourses promote an understanding of indiscipline that is not socially inclusive, in that it helps to fix the problem of indiscipline onto pupils from particular social and ethnic backgrounds. In this section, I look at what is presented as being the costs of indiscipline, that is, why indiscipline is 
thought of as problematic and who we are led to be concerned with when considering disruptive behaviour. There is a considerable variation across the documents analysed, and therefore I looked at the costs associated with indiscipline in general, which very often focus on truancy and exclusion from school. It was possible to discern common elements, which concern the impact of indiscipline on the disruptive pupils themselves, on the wider society, on the school as a whole, on teachers and on other pupils.

A concern with the personal welfare and educational opportunities of disruptive pupils is expressed in many of the documents analysed (Labour Party, 1997; DfEE, 1997, 1999a; DfES, 2002a, b), particularly when issues such as truancy and exclusions from school are being addressed. In particular, the official documents express a concern with pupils' chances of future success (DfEE, 1997, 1999a), risk of disaffection (DfEE, 2001a), and waste of potential (DfES, 2002a). Generally, this is an issue that although being acknowledged is not further explored in the documents, an exception being the Social Exclusion Unit report:

the children themselves lose out because they stop learning. This is self-evident for truants, but it is also a problem for excluded pupils. Many are now receiving as little as three or four hours of tuition each week and some get nothing. These lost years matter: both truancy and exclusion are associated with a significantly higher likelihood of becoming a teenage parent, being unemployed or homeless later in life, or ending up in prison.

(SEU, 1998, p. 1)

Very often, the concern with pupils' welfare is linked to considerations of the social costs of indiscipline. Many government documents on education, such as Circular 10/ 99 (DfEE, 1999a) and several Green and White Papers on education (DfEE, 1997, 2001a; DfES, 2001, 2002a), point to the effects that indiscipline has on the 'outside' community. The SEU (1998) articulates in more detail the association of truancy and exclusion from school with engagement in anti-social and criminal behaviour, and its effects on society:

the wider community suffers because of the high levels of crime into which many truants and excluded pupils get drawn. Time lost from education is a direct 'cause of crime'. For example, in London it has been estimated that 5 per cent of all offences are committed by children during school hours. 40 per cent of robberies, 25 per cent of burglaries, 20 per cent of thefts and 20 per cent of criminal damage in 1997 were committed by 10 to 16 year olds. The police and the public are paying a huge price.

(SEU, 1998, p. 1, emphasis added)

Even though we are lead to expect a concern with the social inclusion of the pupils themselves, the economic costs that the social exclusion of pupils has on society seems to be prioritized. This is also expressed in more recent documents, such as the Green Paper 14-19: Extending opportunities, raising standards (DfES, 2002a):

Wasted potential brings high personal, social and economic costs. For young people themselves the price of disengagement from learning now is often serious problems and persistent failure for the rest of their lives. Low motivation, truancy, behaviour problems and exclusion damage our communities and burden our economy.

(DfES, 2002a, p. 1, emphasis added) 
Again, this questions the Labour Government's commitment to social inclusion, in that it seems that it is the economic burden that indiscipline has on society (in particular, truancy and exclusion from school) that dictates the need to intervene and support pupils.

A third official concern with indiscipline relates to the effect that it has on school, both on the welfare of teachers and pupils. The effect of pupils' misbehaviour on teachers' morale has been featuring increasingly in official documents. There is a concern that pupils' misbehaviour might be driving teachers out of the profession. This is especially interesting at a time of shortage of qualified teachers. This is acknowledged in the 2001 White Paper on education:

We cannot expect to attract and retain good teachers and achieve high standards, unless schools provide a well-ordered and positive environment and teachers have the powers to tackle poor behaviour. The poor behaviour of a few children is a growing problem for teachers and creates anxiety for parents. It is an added source of pressure and a distraction from their prime focus on teaching and learning.

(DfES, 2001, p. 25)

The concern with the impact of indiscipline on teachers' morale and its effect on the recruitment and retention of teachers was indeed taken seriously, and was reflected in changes on the guidance on exclusions from school. New Labour had set a target to reduce the rate of exclusions from school by a third (SEU, 1998), and guidance on discipline (DfEE, 1999a) emphasized that new measures aimed to tackle indiscipline at its early stages to prevent the need to exclude. Having achieved that target by 2001 (DfES, 2001), when the government took its second term in office it softened previous guidance, extending the powers of head teachers to exclude. This move may have reflected the pressure from the National Union of Teachers (NUT) in late 2000. As the Times Educational Supplement announced on 2 November, the NUT required the government to 'Exclude disruptive pupils or we'll strike' (Boyland, 2000). Teachers' difficulty in dealing with perceived escalating misbehaviour was behind such demand, which was accepted by the government. Thus, rather than dealing with social exclusion, New Labour seemed keen to reassure schools and teachers of their power to exclude:

headteachers must have the right to exclude pupils who are violent or persistently disruptive. Individual pupils cannot be allowed to disrupt classes, to the detriment of teachers in the school and the education of their fellow pupils.

(DfES, 2001, p. 26).

The exclusion of pupils who are persistently disruptive had not been contemplated in Circular 10/99 (DfEE, 1999a). Thus, new guidance gave room for head teachers to exclude pupils who would otherwise be attending mainstream schooling. Previous research on exclusions had shown that Black boys are much more likely to be excluded than their peers (Bourne et al., 1994; Blyth \& Milner, 1996), and very often for disobedience rather than violence (Gillborn, 1996). This disproportionate exclusion from school of boys from ethnic minority backgrounds had been acknowledged 
by the government, suggesting the need to avoid racial discrimination (DfEE, 1999a). However, conceding on the need for head teachers to be able to exclude, New Labour compromised on its seeming commitment to social inclusion.

The concern with the welfare of pupils expressed in New Labour's official documents in education relates not only to the pupils who misbehave themselves, but also to their peers who may become distracted in class and thus see their learning disrupted (DfEE, 2001a; DfES, 2001, 2002b):

We have recognised the importance of tackling this issue not just for the benefit of the
poorly behaved pupils themselves who, left unchallenged, could become seriously disaf-
fected but also for other pupils in their classes whose education is disrupted.

(DfEE, 2001a, p. 59)

Indeed, some measures introduced to deal with indiscipline suggest that a main concern with indiscipline relates to the damages it causes on the welfare of others, both teachers and other pupils. For instance, under the Excellence in Cities initiative, New Labour introduced Learning Mentors in urban schools and created Learning Support Units so that children who misbehave are dealt with outside the classroom (DfES, 2001). This suggests that the needs of other children and the teacher are being prioritized. This is also evident in the following quote:

Critically, we will seek to ensure that problems are spotted quickly so that, for example, children with emotional and behavioural difficulties are helped as far as possible before they significantly disrupt the education of others.

(DfEE, 2001a, p. 61, emphasis added)

It is interesting to note how, in this quote, the concern related to those classified as having 'emotional and behavioural difficulties' seems to go with their potential for disruption. Consequently, these pupils are constructed as an obstacle to the success of their peers. Again, it is not their own needs that are being considered. Traditionally, there is an over-representation of pupils from certain minority ethnic backgrounds amongst those categorized as having 'emotional and behavioural difficulties' (Tomlinson, 1981). Recent data indicate that Black boys and those eligible to free school meals are over represented amongst pupils categorized as having 'special educational needs' (DfES, 2003), and that they are disproportionately excluded from school (Parsons, 1999). This suggests that, by focusing on the needs of disrupted pupils, New Labour is addressing those from the middle classes (and mainly White), a particularly important segment of their voters (Tomlinson, 2001; Whitty, 2001).

In sum, I identified in the documents analysed several victims of indiscipline: the pupils who misbehave themselves, the 'outside' community, and the school (both teachers and other pupils). However, when we look closely at how these are conceptualized, it seems that indiscipline matters mainly because of the impact it has on others, rather than because of the opportunities being missed out by the pupils who misbehave. Concerns with the economic costs of social exclusion and with the impact of indiscipline in the recruitment and retention of teachers seem of particular significance. 
Finally, another consequence of the conceptualization of indiscipline in official documents is that it helps to construct pupils as being one of two categories: disruptive or disrupted. The former applies to pupils seen as persistently misbehaving, and the latter to those who are disrupted by the disciplinary events taking place in the classroom. This binary logic is particularly important in that it is a categorization that fixes the problem of indiscipline onto certain pupils. Thus, official documents seem to open a space for the polarization of perceptions of pupils' behaviour (as being disruptive or disrupted), with any consideration of context being downplayed. As I will show in the next section, discipline in real classrooms is much more complex than this approach suggests.

\section{Discipline in context}

Looking at the government's official documents, a powerful discourse on discipline emerges that conceives it as being the result of the education pupils receive at home, and as a matter that should be dealt with to protect teachers and other pupils. Other discourses on discipline also feature, such as a concern with pupils' social inclusion. Nevertheless, these are neither prominent nor reflected in the practices suggested to deal with indiscipline.

As discipline matters were prioritized at the school under study, I decided to explore how teachers' and pupils' understandings of indiscipline in the context of an inner-city, comprehensive school related to what is going on at the policy level. When analysing pupils' and teachers' views, I became aware of the different rationales provided for disruptive behaviour. What I found most interesting was that teachers and pupils used different explanations to talk about disruption. Interviews with pupils suggested that school played a much more crucial role in disruptive behaviour than was generally acknowledged by teachers.

\section{Accounts of the causes of indiscipline}

Previous research carried out by Galloway, Armstrong and Tomlinson (1994) suggested that teachers tend to locate indiscipline 'within child' and 'outside walls' (Watkins \& Wagner, 2000). The data collected through interviews with teachers at Greenfield Comprehensive supported this. Although it was sometimes recognized that the school played a role in indiscipline, the factors identified by teachers (such as the school's leadership and management) suggested that they also preferred explanations of indiscipline as emerging 'outside the walls' of their classrooms.

Teachers used various arguments to explain indiscipline, which can be grouped into five non-exhaustive and non-mutually excluding categories: the individual, the home, the community/culture, the school's leadership, and pupils' subcultures. Despite this variety of explanations, those based on the individual, or on a deficit model of certain families and communities were prominent. The school, its organization, the quality of teaching, the curriculum, or the social interactions taking place daily, were much more rarely, if ever, addressed. 
Pupils, on the other hand, focused on a wider variety of aspects, being particularly critical of the role of school-based factors in the production of indiscipline.

Individualizing indiscipline. As mentioned, individualized accounts of indiscipline were very common at Greenfield Comprehensive, and have been reported in other studies (e.g. Slee, 1995; Gillborn \& Youdell, 2000). Such accounts entailed the association of individual pupils with indiscipline, with teachers not directly referring to issues of ethnicity, gender or class even though this was sometimes implicit. This approach articulated with a view of discipline as a choice free of external constraints, which some authors see as a dominant discourse both in Conservative and Labour governments (e.g. Demaine, 1999; Whitty, 2001). Exception was generally made to pupils with certain medical conditions or so-called special needs:

People like Jamie found it very difficult to be part of the group. Peter, at times, found it difficult to be part of the group, but as time moved on, he was included more and people became more understanding of his own medical difficulties. And children quite often are more understanding, if they can see a reason. $(. . .)^{8}$ Whereas with Jamie, they couldn't see a reason why. Why's he doing that? Why did he behave like that? You couldn't make any sense from it! (...) When he [Jamie] joined in, he was really, really good. When he didn't join in, it was very difficult. There were other students like that, who chose to more or less join ... Sophie, for example was ... was someone who had the capacity to join in if she wanted to, and whenever she didn't want to she sort of sat back and didn't listen and talked to her friends. And you knew she was disengaging from what was going on.

(Ms Clarke, PSE teacher, original emphasis)

It should be noted in the example above how Ms Clarke describes differently the 'disaffection' of Jamie, Peter and Sophie. Jamie, of mixed-heritage and described by teachers as very clever and disruptive, is seen as having a choice not to misbehave. Peter, a White student with Tourette syndrome, is seen as misbehaving because of his medical condition. Sophie, a White girl from a professional family from which teachers had very high expectations, is said to disengage because she got 'bored' with coursework that was thought to be too easy for her. However, even though differentiated expectations of pupils according to their ethnic or social background could be inferred from teachers' discourses and practices, these were rarely made explicit. Discourses on individual pupils were sometimes also based on their gender, with persistent disruptive behaviour or more serious forms of indiscipline been seen as particularly related to boys. Girls were seen to misbehave only occasionally or exceptionally. As a result, it was the behaviour of boys, especially of ethnic minority origins, that posed a real problem for the school (also Mac an Ghaill, 1994; Connolly, 1998). However, by individualizing discourses on the origins of indiscipline, teachers did not acknowledge how they differentiated pupils according to ethnicity, gender and/or class.

Blaming parents and pupils' backgrounds. Parental support was seen by teachers as having a particularly important role in indiscipline. This reflects official discourses 
that locate the origins of indiscipline in the home, the school being merely a site where it manifests itself. In particular, it was suggested that the school by itself cannot deal with the roots of misbehaviour if parents are not supportive and do not pass on to their children a 'good attitude' (Mr Roberts, Head of Year 7). This was a case in which ethnicity and class were encoded, but never spoken out loud. For instance, teachers only rarely addressed the home circumstances of White pupils to explain indiscipline or low achievement. The case of Angela, a White girl who was facing problems at home, ${ }^{9}$ is illustrative. She was often absent, in lessons she always sat on her own, no pupils in 7B chose her as a friend and she preferred to associate with pupils in older year groups. The problems she faced at home were known at the school (I myself learned about them by looking at her school record). However, when talking about her, teachers never mentioned the impact that her family life could be having on her school behaviour and achievement. Conversely, this was a prominent argument in relation to ethnic minority pupils in the form under study, most of whom were not known to be experiencing any kind of family problems. In the eyes of teachers, ethnic minority pupils were, for instance, repressed at home (e.g. Nina, South Asian), or disruptive because they were imitating their fathers (like Joe, African-Caribbean), as illustrated below:

Joe ... He's underachieving. Like mad! He's got ... Family problems. Hmm... He's imitating his father. (...) Nina ... She's ... I met her parents for the first time, and I can now see why she behaves like she is. She's very repressed.

(Ms Miller, form tutor and PSE teacher)

Although it is not clear precisely what Ms Miller meant, she suggested that Nina did not behave appropriately, and that this would be in response to her home atmosphere, which she considered too repressive. In her account, and however unintentionally, she also portrayed Joe's family as pathological by stressing the negative consequences of Joe's father in his misbehaviour. This suggests that teachers' discourses on the origins of indiscipline, largely echoing official discourses, are particularly disadvantaging pupils of ethnic minority backgrounds, whose homes, cultures and subcultures are seen as more 'problematic' in school.

Some teachers saw indiscipline as emerging from a conflict between expectations of behaviour at the home and at the school. In their discourses, the home is presented as a permissive environment that contrasts with the disciplined system promoted by the school. Osler (2000) carried out research on discipline with primary and secondary school pupils, and concluded that generally these see discipline standards at home and at school as being consistent. She also found some pupils from minority ethnic backgrounds who considered their parents stricter than their teachers. Other studies further suggest that pupils' behaviour in school does not directly reflect how they behave at home (Rutter, 1985), and that teachers and parents' perceptions of a child's behaviour often do not match, i.e. a pupil that misbehaves at school does not necessarily do so at home (Graham \& Rutter, 1970). These studies make problematic the conception of indiscipline used in official documents that shift the problem onto family life, downplaying its institutional and contextual dimension. In an interview 
with a teacher that took place in a classroom where two Turkish girls were in detention, she suggested that certain cultures rendered this alleged home-school conflict more acute:

Ms Miller: Hmm ... It's very different from my last school, which was an all-girls school, and which by the time I'd left had very high academic achievement. Hmm ... It's not that different from some of the other schools I've taught in other places. So ... I'm used to this sort of ... students. That's ... that's no different. The biggest difference is that I have not taught Turkish children before. And that's been quite strange. Because their attitude towards education is very different from any of the children I've taught before.

Turkish girl (in detention): Oooh!

Ms Miller: Hmm ... I taught mostly Afro-Caribbean children. And children from the Indian sub-continent. And their parents are often very committed. Even if the children aren't, they are. And I found the same here. That the Afro-Caribbean parents and the African parents are very supportive.

This teacher implies a deficit model that portrays some families and cultural backgrounds as being pathological. Although this was generally not made so explicit by other teachers, and they preferred individualized explanations of indiscipline, they often encoded ethnicity. For instance, another teacher explained disruption as being typical of inner cities, echoing the government's concern with the disciplinary 'problems' of inner-city schools noted in the first section of this paper:

Most of the students are very respectful. They can be ... a bit boisterous, a bit loud ... They're south ... No, they're north [city] teenagers, so ... You know, they're full of wide, varied experiences; they bring their experiences with them to school. It's a very colourful, very colourful atmosphere.

(Ms Akintola, Science teacher)

This particular teacher seems to use the inner city as encoding ethnicity, which can be seen in her use of the expression 'very colourful atmosphere'. As other authors suggest (e.g. Stanford, 2001), she may be associating indiscipline with the pupils of ethnic minority origins, an association that has been documented in many other ethnographies (e.g. Gillborn, 1990; Wright, 1992; Connolly, 1998; Mac an Ghaill, 1988).

School ethos, discipline and control. Not all teachers went looking for the causes of indiscipline within the child or outside the school gates. The school organization, leadership and management were also pointed out as leading to significant changes in pupils' behaviour. In particular, it was suggested that establishing clearer and stricter boundaries of conduct and resorting more often to exclusion had improved pupils' behaviour in their school. However, it is also interesting to note that teachers felt that they were being allowed to have greater control over pupils. For some, it was the fact that 'students are getting away with less' (Ms Babbra, Head of Science Year 10) that improved discipline in the school. Writing on this, Clark (1998) suggested that this approach to discipline as control is all-pervading: teachers often feel that 
control of the class must be secured so that 'delivery' of contents, testing and publication of league tables can take place. In the current context of 'raising standards' (DfEE, 1997), this need for control may be becoming more acute.

When pupils talked about indiscipline, it was the school that they pointed out as creating conditions in which misbehaviour emerged. I do not intend to argue that pupils' interpretations were necessarily any more or less correct or truthful than those of teachers. What is significant is the variety of factors they came to identify within school, factors which, because of their role in the school, teachers seemed more reluctant to acknowledge.

Like teachers, pupils saw the school's leadership and management as helping to improve behaviour. Disruption was thought to have been kept under control when rules became more and stricter. These new rules included Saturday detentions, being sent home for not wearing the right uniform, having a detention for not doing enough work or being late.

Poor teaching. Pupils also saw disruption as being produced in the context of the classroom. In particular, poor quality of teaching was seen as potentially providing the conditions in which indiscipline would breed. Teachers not setting enough work or not explaining what to do, uninteresting lessons, and having too many different supply teachers were amongst the reasons provided to explain indiscipline. It is interesting to note that this particular understanding of the origins of indiscipline was adopted not only by the pupils considered disruptive, but also by those who were generally seen as behaving appropriately. Generally, they agreed that in such conditions they often engaged in small talk with their friends. On many occasions, I also noted how pupils behaved very differently in different subjects. Whenever the teacher was able to keep the lesson flowing smoothly and engage pupils in their work, these were much more likely to behave. However, when they felt the teacher was behind their expectations or they could sense that (s)he was not able to control the class, then more generalized disruption would break out. So generally, pupils tended to prefer stricter teachers who could control the class, and this also applied to pupils who were seen as, or considered themselves, disruptive.

Ahmet: Sometimes I act good, sometimes I get into fights. In English I behave bad, because of the teacher ... He doesn't explain what to do, but Mr Roberts does.

Peter: Yes, generally I'm good behaved in the class. When there's nothing to do then we misbehave.

(Ahmet and Peter, Year 7)

Last year sometimes the teacher couldn't control the class and I started to talk to my friends and just chatting. But if it would calm down, I would stop talking.

(Michelle, Year 8)

Teachers'fairness. If the quality of teaching seemed to have a direct impact on disruption, my analysis of the data suggested that something at a deeper level was 
shaping pupils' attitudes to discipline. This was their perception of teachers' fairness and consistency in the application of disciplinary sanctions. Teachers' efforts to listen to all parties involved in an incident and the application of appropriate sanctions had an enormous impact on pupils' attitudes to discipline (also Pomeroy, 1999; Osler, 2000). And it was here that pupils' opinions and attitudes towards discipline diverged. In relation to the quality of teaching, all the pupils in the form seemed to agree that those teachers who did not teach in an interesting way and were unable to control the class were producing the conditions in which indiscipline would breed. However, when it came to the management of situations of indiscipline and the application of sanctions, attitudes were sharply differentiated. For some pupils, teachers were just human beings with the right to make mistakes, even if this meant that someone would occasionally be treated unfairly:

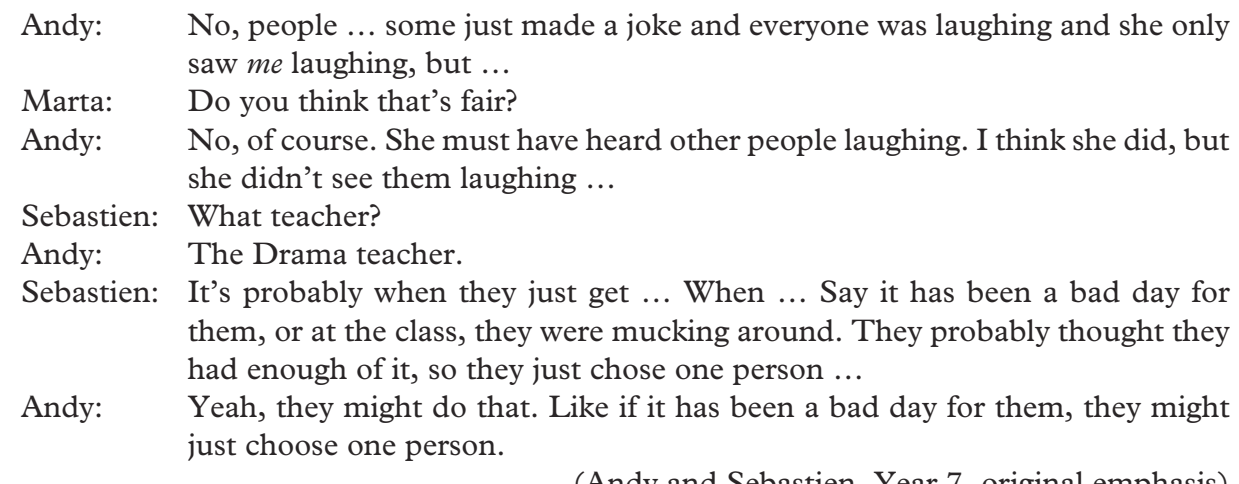

(Andy and Sebastien, Year 7, original emphasis)

For other pupils, like Sinead quoted below, teachers' unfairness threatened their commitment to the school rules, and interactions with teachers were more conflictive in nature. These pupils complained particularly of not being heard when several pupils were involved in the same discipline incident, or for being picked on in lessons:

The worst thing in school ... When the teachers tell you off for no reason, and they don't let you tell your side of the story. And they are not right all the time ....

(Sinead, Year 7)

Whilst teachers' mistakes could be afforded by pupils who were rarely involved in discipline incidents, the others felt strongly that they were never heard and were being discriminated against. This by itself charged interactions with teachers, and often resulted in other situations in which some pupils were disproportionately punished. The case of Joe, a pupil in Year 7 who was racially harassed by a supply teacher was illustrative of this. I was not observing this teacher's lessons, and Joe himself did not complain directly to me about this. Nonetheless, Joe's peers in 7B told me that Mr Evans picked on pupils from minority ethnic backgrounds, often making derisive remarks about their physical appearance or dressing style. In Joe's case, he was scorned because of his haircut (styled in short locks). In a meeting with Sinead (7B), her mother and the Head of Year 7, this issue was brought up to Mr Roberts's attention: 
The Head of Year 7, Sinead and her mother talk about English lessons. Sinead says, 'Everyone is horrible to the teacher'. (...) They talk once more about Mr Evans, the English teacher. Sinead says he gives them work that he doesn't explain, and that everyone is rude to him as a result. Mr Roberts suggests that she can help the others change their attitude towards the teacher. (...) Then she talks about a comment the English teacher made to Joe about his haircut. Mr Roberts replies, 'That's a bit racist. You can't change it'.

(Fieldnotes, Head of Year 7's meeting with Sinead and her mother)

Joe was initially considered the 'cleverest pupil in Year 7' (Mr Roberts, Head of Year 7). Although he behaved well with some teachers, he started having disciplinary problems with others, generally because of what was perceived as opposition to petty authority. This was particularly acute in the lessons from whose teacher he suffered racial abuse. The school did not take serious action to deal with this situation. When some of Joe's peers complained about the teacher's behaviour, the Head of Year commented, 'That's a bit racist. You can't change it!' (Mr Roberts). In addition, he asked pupils to show more support to that particular teacher. Throughout the school year, Joe's behaviour deteriorated and became more generalized. Eventually, he left the school. This is an example of the roots of discipline issues not being addressed by the school, with some pupils reacting in a way which further disadvantages themselves.

Bullying and pupils' cultures. Although focusing mostly on teaching practices, pupils also saw indiscipline as resulting from interactions between pupils. Bullying and unresolved disputes between pupils or groups of pupils often resulted in confrontations in the classroom, and this, in turn, led to confrontation with the teacher. As Osler (2000) points out, problems between pupils can lead to violence and disruption in the classroom. At the form under study, this was a serious issue with two groups of pupils often in conflict. This case assumed racialized contours, with pupils positioning themselves in opposite sides according to their ethnicity. ${ }^{10}$

Other pupils thought that misbehaviour was not only a response to on-going conflicts, but also a way that their peers had to 'show off' and gain popularity. Ignoring the teacher's instructions, walking about in class or just chatting all the time were seen as 'cool' by some pupils. Particularly outside the classroom, pressure was often placed on boys to engage in fights, at the expense of getting 'beaten up for being a chicken' (Julia, Year 7). Intimidation was seen as an attempt to demonstrate physical superiority over smaller or younger boys by pupils pursuing popularity through an image based on 'toughness'. ${ }^{11}$ For those boys who tried to avoid this pressure, 'it's either getting bullied or getting beaten up' (Terry, Year 7). A generalized perception amongst pupils of the school's insufficient action in relation to bullying led pupils such as Terry to play truant and leave the school, because he felt he was not protected there.

Some teachers also referred to the role of pupils' subcultures in promoting indiscipline, and particularly to the pressure placed on pupils to pretend that they were not 'goodie-goodies' and to be disruptive (Mac an Ghaill, 1994; Sewell, 1997). Some 
teachers acknowledged that they themselves had also been through that, to gain popularity amongst their peers. However, even though acknowledging that pupils may not show commitment to school because of peer pressure, and having experienced it themselves, teachers did not seem concerned to address such issues.

In sum, it was apparent at Greenfield Comprehensive that teachers preferred 'within-child' or 'outside walls' (Watkins \& Wagner, 2000) explanations of indiscipline. Such an approach to discipline downplays the role of the school, and thus allows for a limited teacher role in changing pupils' behaviour. In particular, teachers tended to use a deficit model, pointing to the differences between the culture of school and that of pupils' homes and communities to explain disruption. In relation to the role of the school, this was limited to its organizational and management aspects. Some thought that a strong leadership and clearer rules to control pupils' behaviour had helped pupils in better understanding what was expected of their behaviour and to act accordingly. However, the quality of teaching and the curriculum were never pointed out as making a difference in pupils' behaviour. The prevalence of factors centred on the children, their families and communities suggests the popularity of educational psychology approaches to indiscipline amongst teachers, as well as policy-makers (Slee, 1995). Thus, teachers' discourses were mostly supportive of New Labour's approach, both in how indiscipline is conceived of, and the philosophy behind intervention (that is, attacking the symptoms of indiscipline, leaving aside its institutional and political dimensions).

Pupils, on the other hand, generally focused on the role of the school context in producing indiscipline, addressing in their explanations several levels in which indiscipline emerged, such as the school management, the classroom and individuals. It is interesting to note that in spite of being just 11 year olds, pupils showed a very critical insight into the school structures and organization and their role in the production of indiscipline.

\section{What counts as discipline for pupils and teachers}

Pupils generally defined discipline as compliance to school rules. Not listening to the teacher, chatting in class, walking around, throwing things across the classroom, playing truant, were all seen as inappropriate behaviour in school. And even though they would not necessarily comply with those rules, pupils agreed that to break school rules was against the school's expectations of behaviour. Furthermore, behaviour was seen as an important criterion to categorize someone as the "best"12 pupil, or else exclude him/her from the 'ideal' pupil position. Thus, someone who was considered a good pupil but was thought of as being too chatty or as being often absent was never defined as being one of the 'best' pupils in class. This applied not only to the positioning of other pupils, but also to how pupils positioned themselves. For instance, in an interview with two pupils, Jamie and Ismail, they told me that they thought they had the potential to be the 'best' pupils in class, but that they misbehaved, played truant and got involved in fights. This was used by Jamie to exclude them both from that position, as the following quote depicts: 
We ain't got good behaviour ... (...) If you don't behave ... you don't get a chance to show how clever you are. So you have to behave and then you have to show how clever you are.

(Jamie, Year 7)

Thus, for pupils it was compliance to rules that was the most influential criterion in defining discipline.

When teachers defined an 'ideal' pupil in terms of discipline, they also stressed the importance of complying with the school's stated rules, such as being punctual, being quiet, listening to the teacher or bringing in the appropriate material for lessons. This is a definition of discipline based on the compliance with school rules. It defines precise expectations of pupils' behaviour, and criteria against which to measure indiscipline. However, my analysis of interviews with teachers suggested that what counts as indiscipline is something more than behaviour that is against school rules. For teachers, it was 'attitude' that really mattered. The pupils considered the 'best' in the form did not always comply with rules. Occasional misbehaviour was acceptable, as long as pupils were perceived to have a 'good attitude' towards teachers, the school and education in general. The following example is illustrative:

Sebastien is the ideal pupil. He's intelligent, he's helpful, he's friendly, he's not like some
little goodie-goodies. Like quite trendy, he's good at everything. He's good at sports, he's
good at music. Quite clever. Not like, genius, genius! But pretty good. He's helpful, he's
popular with the other kids. He's just a very, very good kid. And ... Lucy. Fantastic kid as
well. Again, not the genius, but she's good at everything. Good at sports, clever, works
hard, friendly, pleasant, popular. They've both been on trips with me. They both came on
the big trip last summer, but Lucy came on the smaller trips as well. Sebastien went on the
trip last summer. Lucy came on the trip this autumn. Hmm ... Basically, good attitude!

(Mr Roberts, Science teacher and Head of Year 7, emphasis added)

This teacher commented that Sebastien was not a 'goodie-goodie'. Sebastien himself acknowledged this. In an interview in which I asked him to describe himself as pupil, he told me that he was 'a little bit short-tempered', and that although he usually brought the required equipment to school, sometimes he 'just can't be bothered to take it out'. Thus, as Sebastien himself says, he did not always comply with rules. However, his 'good attitude' made all the difference in winning teachers' approval. With Lucy, another pupil in the form, the same happened. Many times I observed her engaging in small talk in the classroom, without being reprimanded. Sometimes this was at the expense of her friend Nina, who used to sit with her. When I interviewed the two of them, they gave me several examples of Nina being wrongly accused. Lucy suggested that even when she misbehaved, she would get away with it quite easily.

The importance given by teachers to perceptions of pupils' attitudes placed adjectives such as 'helpful', 'friendly' and 'pleasant' at the core of definitions of discipline. Compliance to school rules was expected, but was not sufficient to describe someone as a well-behaved pupil. What Sebastien and Lucy had that was recognizably different from many of their peers was their 'attitude'. They were particularly supportive of teachers, misbehaved in less visible ways and acquiesced to teachers' orders whenever they were reprimanded. As a result, with Sebastien and Lucy interactions with 
teachers would not escalate into situations of conflict. This helped them to get support from other teachers as well. One teacher told me that she thought Sebastien could get away with more than his peers normally would:

\begin{abstract}
I mean their relation with Steven [Roberts], who is the head of the Year, probably changed over the time. 'Cause I know people like Sebastien, he developed quite a good relationship ... 'Cause, you know?, people like Sebastien would want to go on a trip, and would want to go camping, and ... They were interested in the same sort of things. So Sebastien, I think would probably say things to him that some of the other students couldn't dream of saying to the head of year! 'Cause Sebastien gets away with it, whereas you know some of the others would be quieter....
\end{abstract}

(Ms Clarke, PSE teacher, original emphasis).

Note how cultural capital comes into play here. Bourdieu (1994) defined cultural capital as opportunity of access to, and a set of dispositions towards, legitimate knowledge and cultural goods. As the data I collected and this teacher in particular suggested, Sebastien shared with Mr Roberts the same cultural interests and background. He was allowed to do things that other pupils could not even dream of because he showed the 'right attitude'. Thus, pupils' actions in the classroom (such as pupils being involved in small talk or walking about) did not necessarily define indiscipline. Rather, it was teachers' perceptions of pupils' attitudes combined with misbehaviour that allowed the former to make judgements about the seriousness of indiscipline. Having a 'good attitude' towards the school and education was what enabled teachers to define well-behaved pupils, and this encoded particular cultural capital.

\title{
Disruptive and disrupted pupils
}

Most pupils, but few teachers, interviewed at Greenfield Comprehensive worked with a notion of discipline that was based on following rules, which could be clearly used to define what counts as indiscipline. My analysis of interviews with teachers suggested that perceptions of pupils' attitudes were prominent in their conceptions of discipline. This approach to indiscipline helped teachers in defining who was disruptive and disrupted, two mutually excluding categories that I also saw emerging in New Labour's official documents on discipline. Foucault's concept of the formative power of discourse was particularly useful in understanding this. He defines discourses as:

practices that systematically form the objects of which they speak. ... Discourses are thus not about objects; they do not identify objects, they constitute them, and in the practice of doing so conceal their own invention.

(Foucault, 1977, p. 49).

The ethnographic study I carried out at Greenfield Comprehensive showed that these categories cannot easily be used to describe particular pupils. The complex reality of discipline in the classroom cannot be explained by a binary logic that categorizes pupils as either disruptive or disrupted. Most pupils would position themselves 
somewhere between both, and even those who could be seen as merely disruptive and disrupted were mostly doing so in specific contexts. These socially constructed categories are not only presented in official discourses but are also in evidence at the school level. At Greenfield Comprehensive, pupils seen as disruptive were not only those who breached the school rules, but also those who were perceived to have a 'bad attitude'. Disrupted pupils, on the other hand, were occasionally allowed to misbehave because of perceptions of their 'good attitude' towards school and teachers. This was of particular importance so far as it informed social interactions in the classroom. An example of this was that of Sophie, the daughter of a professional couple. Greenfield Comprehensive was a school attended by pupils who were mainly from working class backgrounds. Sophie's social status was highly regarded amongst some teachers, and was registered in her school record ${ }^{13}$ (which did not happen with any of her peers in the form). Teachers had very high expectations from Sophie, and explained her misbehaviour as disengagement by her being 'too able' to follow the same pace as her peers. Thus, teachers tended to overlook her misbehaviour even though Sophie herself acknowledged that she sometimes misbehaved. Her peers suggested that she often got away with not complying with teachers' instructions or handing in homework. Interestingly, in spite of teachers policing her behaviour and pressing her to conform to their high expectations, Sophie showed great ambivalence in how to define herself. On the one hand, she did not think she was well behaved because she often engaged in small talk during lessons. On the other hand, some of her teachers and peers were enforcing a positive reputation, positioning her as a disrupted pupil. This was illustrated in Sophie's saying that teachers reminded her in lessons that she was 'not like the others' and therefore should not misbehave.

Marta: $\begin{aligned} & \text { Thinking about the school as a whole, do you think teachers treat everyone } \\ & \text { fairly? Give some examples. }\end{aligned}$
Sophie: $\begin{aligned} & \text { Yes, but all the other kids they don't know how to react. } \\ & \text { Julia: }\end{aligned}$ Not really ... We don't ... In a way, it's good, because they don't like to single
you out. So the bad people ... get mixed with the girls, and all. We get mixed
in our class. I think they treat us fairly.
Sophie: $\quad \begin{aligned} & \text { Yes, they treat us fairly ... Let's say if you have a question and you, like, you put } \\ & \text { your hands up ... They would eventually ask you. (...) Even with the really } \\ & \text { disruptive ones, they still treat them fairly. }\end{aligned}$
Julia:
And if some people ...
They're a bit forgetful (both laugh), 'cause they say I'll give you detention and
they forget! What's the point? (...) If one person acts bad ... If YOU don't act
like they think you should, then they'll say, 'Why aren't you acting like you should,
because you're not like the others, you're not stupid or anything'. Not that the others
are stupid! (laughs)

(emphasis added)

There was a tension between teachers' expectations of her and how Sophie defined herself as a pupil. Wider discourses that present indiscipline in a binary logic, which create the categories of disruptive or disrupted pupils, seemed to be producing such ambiguity. Despite this, teachers' high expectations of her were solving this tension, and reinforced her positioning as disrupted. Arguably, it was Sophie's socially 
advantaged background that contributed to her being positioned in such a way. Other studies documented how the pupils who were perceived by teachers as 'ideal' (Becker, 1952) - generally from a middle-class background - were more likely to be advantaged in the classroom (Sharp \& Green, 1975). The case of Ismail, a Turkish-Cypriot boy, is also illustrative of this polarization of pupils. Teachers had very low expectations of Ismail in terms of behaviour and school work, and his attempts to change his behaviour were overlooked in a context of poor expectations from pupils of some ethnic minority origins. For instance, although Ismail separated from his best friend to gain teachers' approval, these were reluctant to acknowledge his commitment to school and to see his improving behaviour as being voluntary and intentional.
Marta: Who are your best friends in school?
Ismail: Moktar [who was also in 7B].
Marta: Why do you hang around together?
Ismail: I don't really hang around, but because I don't get a chance to speak to him, really. And when I look for him I can't find him. 'Cause he likes the same things that I do, and we watch the same programmes and stuff like that. Like Art.
Marta: Was he also your best friend last year?
Ismail: $\quad$ Yeah... And I had Ahmet. He was my best friend last year, but I can't speak with him anymore, 'cause he moved. And my brother told me not to speak to him 'cause he makes me look to the teachers as if I'm a naughty boy. I don't think that, but my brother does.

(Ismail, Year 8).

Marta: How do you think Ismail and Ahmet are getting along (in their new forms)?

Teacher: Hmm ... They're still in quite a lot of trouble, as far as I can gather. Ahmet keeps on coming in (the classroom) and being a nuisance. And I've taught Ismail a couple of times this term and he's just about managed to keep out of trouble. But I think ... so I think they're separated, and I think that's helped them.

(Ms Miller, form tutor and PSE teacher)

Ismail suggested that he did not stop hanging around with Ahmet merely because they were now in different forms. Teachers, however, saw Ismail's change as resulting from their intervention (separating him from his friend), thus playing down and not encouraging his commitment to school, and limiting his success in contesting his positioning as disruptive.

Previous research illustrated how certain pupils, particularly boys from ethnic minority backgrounds, tend to be at risk of being perceived as having the 'wrong attitude', being more often disciplined than their peers (Mac an Ghaill, 1988; Gillborn, 1990; Wright, 1992; Sewell, 1997; Connolly, 1998). My own study supported this evidence (Table 1). When examining Table 1, the absence of any Turkish and Black girls in the form under study should be noted. Moreover, the absolute number of pupils is relatively small, particularly when ethnicity, gender and class are broken down in each cell. Nevertheless, I think some conclusions can still be drawn from the data presented. 
Table 1. Number of detentions received by pupils in $7 \mathrm{~B}$ throughout Year 7

\begin{tabular}{|c|c|c|c|c|c|}
\hline & \multicolumn{2}{|c|}{ Boys } & \multicolumn{2}{|c|}{ Girls } & \multirow[b]{2}{*}{ Subtotals } \\
\hline & $\mathrm{FSM}^{\star}$ & No FSM & FSM & No FSM & \\
\hline White & $20(3)$ & $17(3)$ & $3(2)$ & $9(6)$ & $49(14)$ \\
\hline Turkish & $47(2)$ & - & - & - & $47(2)$ \\
\hline Black $\star \star$ & $50(4)$ & $8(2)$ & - & - & $58(6)$ \\
\hline South Asian & $0(1)$ & - & - & $1(2)$ & $1(3)$ \\
\hline Subtotals & $117(10)$ & $25(5)$ & $3(2)$ & $10(8)$ & $155(25)$ \\
\hline Total & & $142(15)$ & & $13(10)$ & $155(25)$ \\
\hline
\end{tabular}

${ }^{\star}$ FSM, free school meals; ${ }^{\star \star}$ African and African-Caribbean pupils.

Figures in parentheses refer to absolute number of pupils in that category.

In the form under study, during the whole of the school year 25 pupils received 155 incident reports relating to detentions. Amongst these, four pupils had not received any detention. These were two White girls, and two South Asian pupils, a girl and a boy. When I broke down the data by gender, social background ${ }^{14}$ and ethnicity, some patterns began to emerge. The use of detentions was clearly gender differentiated. In $7 \mathrm{~B}$, boys were seven times more often in detention than girls. The fifteen boys accounted for 142 detentions, whilst ten girls had only received thirteen detentions for misbehaviour. The number of detentions received by pupils eligible for free school meals was also disproportionately higher relative to those who were not. This was particularly true where boys were concerned. In relation to ethnicity, Turkish and Black boys received proportionately more detentions than their peers of other ethnic origins. Two Turkish boys accounted for nearly a third of all detentions received in 7B. Thus, my own study at Greenfield Comprehensive suggests that pupils from ethnic minority and disadvantaged backgrounds were being more severely punished than their peers. As illustrated in the examples provided, when teachers relied on 'attitude' to define misbehaviour, they would often overlook the misbehaviour of those pupils considered 'ideal' (Becker, 1952). These were mostly White, middle-class and/ or girls. Thus, discourses on discipline at the policy level seem to be producing a definition of indiscipline that ultimately disadvantages pupils of ethnic minorities. A deficit approach to pupils' families and cultures, associated with teachers' understanding of discipline as a matter of 'attitude' compounded a picture in which Turkish and Black boys were seen as a disciplinary 'problem'. Some teachers at Greenfield Comprehensive even wanted to see some of them removed from school. And in spite of looking outside the school for the origins of indiscipline, teachers rarely acknowledged its social costs, either at the level of individuals or more widely.

\section{Conclusions}

Although New Labour brought social inclusion into the education agenda, this move seems largely rhetorical. In this paper, I showed that the conception of 
indiscipline put forward by official documents is simplistic and reductionist, and dismisses its contextual and social dimensions. As a result, indiscipline is presented as a 'problem' of inner-city pupils in particular, and one that emerges from factors such as their homes and cultures, or their individual deficits. Importantly, this conception of indiscipline helps to blame the victims of traditional educational inequalities. A concern with the social and economic costs of indiscipline (on society, teachers and other pupils) seems also to be prioritized over the needs of the pupils who misbehave, thus questioning New Labour's commitment to social justice for these pupils.

Furthermore, this conception of indiscipline results in measures to tackle indiscipline that tend to focus on support for, and punishment of, the pupils who misbehave and their families, shifting the problem onto them. The school is seen as contributing merely to the amelioration of the behaviour previously acquired at home. The roles of the curriculum, the quality of teaching and the social interactions taking place at school are largely downplayed. Consequently, the institutional, political and contextual dimensions of indiscipline are not made problematic. Slee (1995) suggests that this approach reflects the growing influence of education psychology, which has been providing attractive 'quick-fix' solutions for policy-makers and schools to deal with indiscipline. He adds that an approach to indiscipline that does not consider school improvement is inevitably of limited impact. Moreover, as Macrae et al. (2003), drawing on the work of Viet-Wilson (1998), argue, a 'weak' version of social exclusion (one that merely attempts to include the excluded) is not sufficient to deal with current inequalities in education, as it fails to address the operation of institutional mechanisms of social exclusion.

At Greenfield Comprehensive, teachers were also largely supportive of an approach to indiscipline that tends to pathologize certain pupils and communities, reworking it within the specific context of the school and of particular individuals. Teachers referred to wider discourses on 'race', gender and class to differentiate the indiscipline of pupils, even though they individualized them. Discourses on the origins of indiscipline were multiple and contradictory. The same teacher would rely on different sorts of arguments to explain the behaviours of two undisciplined pupils. More importantly, the discourses used to explain the misbehaviour of a pupil were not always made available to other pupils. For instance, teachers only rarely addressed the home circumstances of White pupils to explain indiscipline or low achievement. Such discourses, however, served to disadvantage the pupils from ethnic minority backgrounds.

Noticeably, official and teachers' understandings of indiscipline opened a space for the polarization of perceptions of pupils' behaviour, as being either disruptive or disrupted. However, indiscipline in real classrooms is more fluid than official and teachers' discourses allow. Disruptive pupils are not always disruptive, as those who tend to behave well are not necessarily disrupted or behave well on all occasions. In a given classroom situation it may only be possible to position a couple of pupils at each extreme end of a behaviour spectrum, but most pupils would fall in the middle. Pupils do not merely slip into disruptive or disrupted 
bodies; rather, discipline is negotiated daily in classrooms through interactions with both teachers and peers. It might to some extent reflect particular problems that pupils are facing at home, but often also seems to result from processes taking place at the school. Using a binary logic which positions pupils as being either disruptive or disrupted obscures the contextual dimension of indiscipline, not acknowledging the processes, school based and others, that promote it. This contextualization of indiscipline is particularly important because it offers a way forward, especially in helping teachers to think critically about their disciplinary practices and expectations of pupils. Teachers often used their expectations of pupils to explain indiscipline, denying some the opportunity to negotiate positive interactions in school.

The consequences of this binary logic are of particular importance insofar as it articulated with teachers' perceptions of pupils' attitudes. Pupils who were perceived as having the 'right attitude' to school and education needed not be 'goodie-goodies' to be positioned as disrupted, and tended to be from more advantaged backgrounds and mainly White. Girls were also more often positioned in this category, being seen as obedient, hard working and at most 'chatty'. Pupils positioned as disruptive were disproportionately boys of Turkish and African-Caribbean descent, being more often described as having a 'bad attitude' and receiving more detentions. Teachers' reworking of official discourses on discipline not only helped them define pupils' nature as disruptive and disrupted, according to perceptions of 'attitude', but also shaped social interactions with pupils, reinforcing differences between those positioned in the two categories. The misbehaviour of pupils falling into the category of disrupted, was more likely to go unnoticed by teachers. Conversely, the efforts of pupils seen as disruptive were generally downplayed by teachers. This meant that perceptions of gender differences and a deficit approach to pupils of ethnic minorities positioned certain pupils at risk of having 'bad attitude' and being disruptive, closing down educational opportunities. Despite this, the association of ethnicity with behaviour was less visible in pupils' and teachers' discourses. This was because associations of indiscipline were made at the level of individuals, with Turkish and Black boys being often mentioned when teachers or pupils talked about it. Often framed in discourses of discipline as a choice, these discussions of misbehaviour at the level of individuals masked how ethnicity and gender influenced the range of schooling identities available for these pupils. Thus, this paper points to the need for teachers to challenge the comfortable, but dangerous, stereotypes that circulate in relation to social class, 'race' and gender, as a means to move towards social inclusion.

\section{Acknowledgements}

The author acknowledges the advice and assistance provided by Professor David Gillborn, Institute of Education, University of London. The author also acknowledges financial support from the Portuguese agency FCT (Research Grant PRAXIS $\mathrm{XXI} / \mathrm{BD} / 15537 / 97)$. 


\section{Note on contributor}

Marta Araújo is currently a full-time researcher at the Centre for Social Studies of the University of Coimbra, Portugal. She carried out her doctoral studies in Sociology of Education at the University of London, Institute of Education, UK.

\section{Notes}

1. The real names of the school and of all teachers and students were changed to preserve anonymity.

2. This was one of New Labour's flagship initiatives to raise 'standards' introduced in 1997 (DfEE, 2001b).

3. This expression was borrowed from Ball et al. (2000), which is preferred to the term 'refugee', as it better encapsulates the fragility, and contextual specificity, of the concept.

4. The constant absenteeism of the remaining three pupils in $7 \mathrm{~B}$ was the reason why they were not interviewed.

5. By this time, I was only able to interview 17 pupils, as some had left the school or were repeatedly absent.

6. The sections on exclusions from school were subsequently amended.

7. This discourse, Tomlinson (2001) argued, was commonly used in the 1960 s by both the Conservative and Labour Parties to explain the poor educational performance of working-class pupils.

8. In the transcripts, the following conventions have been used: Italicized text, emphasized speech, in the original or added; (...), text edited out; ..., pause of speech; ' ', direct quotation; [ ], background information, including the name of the speaker, body movement or posture, emotion, tone of voice, interruption.

9. A close member of the family had been the victim of a violent incident, and they were subsequently re-housed.

10. Further details on this are available in Araújo (2003).

11. A number of studies have explored how school behaviour articulates with the construction of particular versions of masculinity (e.g. Mac an Ghaill, 1994; Sewell, 1997; Connolly, 1998).

12. In interviews, I deliberately did not specify what I meant by 'best pupil' to explore pupils and teachers' own understandings of the concept.

13. In her record, the following information was provided: 'Parents: mother - director/lecturer; father - designer'.

14. In common with official statistics in the UK, I used eligibility for free school meals as a proxy for social background, as there were no other data available.

\section{References}

Alexiadou, N. (2002) Social inclusion and social exclusion in England: trends in education policy, fournal of Education Policy, 17(1), 71-86.

Araújo, M. (2003) Discipline, selection and pupil identities in a Fresh Start school: a case study. PhD thesis, Institute of Education, University of London.

Ball, S. J., Maguire, M. \& Macrae, S. (2000) Choice, pathways and transitions post-16: New youth, new economies in the global city (London, Routledge Falmer).

Barton, L. \& Slee, R. (1999) Competition, selection and inclusive education: some observations, International fournal of Inclusive Education, 3(1), 3-12.

Becker, H. S. (1952) Social class variations in the teacher-pupil relationship, fournal of Educational Sociology, 25, 451-465. 
Blair, T. (2002) Standards, discipline and choice. Speech by the Prime Minister at Abraham Moss High School, Manchester, 22 March 2002. Available online at: http://www.number10.gov.uk/news.asp?NewsID $=3865 \&$ SectionId $=32$

Blyth, E. \& Milner, J. (1996) Exclusions: trends and issues, in: E. Blyth \& J. Milner (Eds) Exclusion from school: Inter-professional issues for policy and practice (London, Routledge) 3-20.

Bourdieu, P. (1994) Practical reason (Oxford, Polity).

Bourne, J., Bridges, L. \& Searle, C. (1994) Outcast England: How schools exclude black children (London, Institute of Race Relations).

Boyland, R. (2000) NUT: exclude disruptive pupils or we strike, Times Educational Supplement, 2 November.

Clark, C. (1998) Discipline in schools, British fournal of Educational Studies, 46(3), 289-301.

Connolly, P. (1998) Racism, gender identities and young children (London, Routledge).

Dean, C. (1998) Standards are not parents' top priority, Times Educational Supplement, 9 October.

Demaine, J. (1999) Education policy and contemporary politics, in: J. Demaine (Ed.) Education policy and contemporary politics (London, Macmillan).

DfE (1992) Choice and diversity (London, HMSO).

DfEE (1997) Excellence in schools (London, HMSO).

DfEE (1999a) Circular 10/99 social inclusion: Pupil support (London, DfEE).

DfEE (1999b) Excellence in cities (London, DfEE).

DfEE (2001a) Schools extending excellence: Excellence in cities report March 1999 to September 2000 (London, DfEE).

DfEE (2001b) Experience of Fresh Start. Available online at: http://www.standards.dfee.gov.uk/ schoolimprovement/pdf/fresh_start.pdf

DfES (2001) Schools achieving success (London, HMSO).

DfES (2002a) 14-19: Extending opportunities, raising standards (London, HMSO).

DfES (2002b) Transforming secondary education: The middle years. Speech by the Rt Hon. Estelle Morris MP, Secretary of State of Education and Skills, 21 March 2002 (London, Demos).

DfES (2003) Statistics of education: Special educational needs in England: Fanuary 2003. Available online at: http://www.dfes.gov.uk/rsgateway/DB/SBU/b000429/specialneeds.pdf

Edwards, T., Whitty, G. \& Power, S. (1999) Moving back from comprehensive secondary education?, in: J. Demaine (Ed.) Education policy and contemporary politics (London, Macmillan) $30-64$.

Foucault, M. (1977) The archaeology of knowledge (London, Tavistock).

Galloway, D., Armstrong, D. \& Tomlinson, S. (1994) The assessment of special educational needs: Whose problem? (Harlow, Longman).

Gamarnikow, E. \& Green, A. (1999) The third way and social capital: Education Action Zones and a new agenda for education, parents and community?, International Studies in Sociology of Education, 9(1), 3-22.

Gillborn, D. (1990) Race, ethnicity and education: Teaching and learning in multi-ethnic schools (London, Unwin Hyman \& Routledge).

Gillborn, D. (1996) Exclusions from school, Viewpoint, no. 5.

Gillborn, D. \& Youdell, D. (2000) Rationing education: Policy, practice, reform and equity (Buckingham, Open University Press).

Glaser, B. \& Strauss, A. (1967) Discovery of grounded theory (Chicago, Aldine).

Graham, P. \& Rutter, M. (1970) Selection of children with psychiatric disorders, in: M. Rutter, J. Tizard \& K. Whitmore (Eds) Education, health and behaviour (London, Longman) 147-177.

Hill, D. (2001) Equality, ideology and education policy, in: D. Hill \& M. Cole (Eds) Schooling and equality: Fact, concept and policy (London, Kegan Page) 7-34.

HMSO (1998a) School Standards and Framework Act 1998 (London, HMSO).

HMSO (2002) The Education Act 2002 (London, HMSO).

Labour Party (1995) Excellence for everyone: Labour's crusade to raise standards (London, Labour Party). 
Labour Party (1997) New Labour because Britain deserves better (London, Labour Party).

Labour Party (2001) Ambitions for Britain. Available online at: http://www.labour.org.uk

Mac an Ghaill, M. (1988) Young, gifted and black (Milton Keynes, Open University Press).

Mac an Ghaill, M. (1994) The making of men: Schooling, sexualities and masculinities (Buckingham, Open University Press).

Macrae, S., Maguire, M. \& Milbourne, L. (2003) Social exclusion: exclusion from school, International fournal of Inclusive Education, 7(2), 89-101.

OFSTED (2001) The annual report of Her Majesty's Chief Inspector of Schools 2000-2001 standards and quality in education (London, HMSO).

Osler, A. (2000) Children's rights, responsibilities and understandings of school discipline, Research Papers in Education, 15(1), 49-67.

Parsons, C. (1999) Education, exclusions and citizenship (London, Routledge).

Pomeroy, E. (1999) The teacher-students relationship in secondary school: insights from excluded students, British Fournal of Sociology of Education, 20(4), 465-482.

Power, S. \& Gerwitz, S. (2001) Reading Education Action Zones, fournal of Education Policy, 16(1), 39-51.

Rutter, M. (1985) Family and school influences on behavioural development, fournal of Child Psychology and Child Psychiatry, 26(3), 349-368.

Sewell, T. (1997) Black masculinities and schooling: How black boys survive modern schooling (London, Trentham).

Sharp, R. \& Green, A. (1975) Education and social control: A study in progressive primary education (London, Routledge \& Kegan Paul).

Slee, R. (1995) Changing theories and practices of discipline (London, Falmer).

Social Exclusion Unit (SEU) (1998) Truancy and School Exclusion Report. Available online at: http://www.socialexclusionunit.gov.uk/published.htm\#pub_reports

Stanford, J. (2001) Race, Labour and the archbishop, or the currency of race, Race, Ethnicity and Education, 4(1), 83-97.

Strauss, A. \& Corbin, J. (1998) Basics of qualitative research: Techniques and procedures for developing grounded theory, 2nd Edn (London, Sage).

Tomlinson, S. (1981) Educational sub-normality (London, Routledge \& Kegan Paul).

Tomlinson, S. (2001) Education in a post-welfare society (Buckingham: Open University Press).

Viet-Wilson, J. (1998) Setting adequacy standards (Bristol, Policy).

Vincent, C. \& Tomlinson, S. (1997) Home-school relationships: 'The swarming of disciplinary mechanisms'?, British Educational Research fournal, 23(3), 361-376.

Watkins, C. \& Wagner, P. (2000) Improving classroom behaviour (London, Paul Chapman \& Sage).

Webster, D. (2001) Beacon Schools: New Labour education policy in a nutshell, Forum, 43(3), $127-130$.

Whitty, G. (2001) Education, social class and social exclusion, fournal of Educational Policy, 16(4), 287-295.

Wright, C. (1992) Race relations in the primary school (London, Fulton). 